\title{
Use of I-geo and enrichment factor in assessing soil pollution status around auto-mechanic workshop clusters in Yenagoa, Bayelsa State, Nigeria
}

\author{
Bariweni, P. A. ${ }^{1}$, Amukali, $0 .{ }^{1 *}$ and Imaitor-Uku, E. E. ${ }^{2}$ \\ 1Department of Geography and Environmental Management, Niger Delta University, Amassoma, Bayelsa State, Nigeria. \\ ${ }^{2}$ Department of Geography, Isaac Jasper Boro College of EducationSagbama, Bayelsa State, Nigeria. \\ ${ }^{*}$ Corresponding author. Email: amukaliogo@yahoo.com. Tel: +2348136152810.
}

Copyright @ 2018 Bariweni et al. This article remains permanently open access under the terms of the Creative Commons Attribution License 4.0, which permits unrestricted use, distribution, and reproduction in any medium, provided the original work is properly cited.

Received 5th July, 2018; Accepted 14th August, 2018

\begin{abstract}
Heavy metals could be induced into new environments either naturally or anthropogenically. Anthropogenic input of heavy metals into soils has been on the increase in recent years in various towns and cities as it is a major means through which heavy metals that were not indigenous to a given geographical area could be introduced into new environments. The need to ascertain the exact anthropogenic activities responsible for discharge of heavy metals into man's environment can never be over-emphasized. Therefore, this work focused on ascertaining the current pollution status and contributory source of heavy metals around soils of auto-mechanic workshop clusters in Yenagoa Metropolis, Bayelsa State, Nigeria. Three upper soil layers $(0$ to $15 \mathrm{~cm}, 15$ to $30 \mathrm{~cm}$ and 30 to $45 \mathrm{~cm})$ were sampled over three distant extremes ( 0 meter, 50 meters and 100 meters) and analyzed. Values of i-geo showed that $\mathrm{Zn}(2.23)$ showed moderate to highly polluted geogenically while $\mathrm{Pb}(0.76), \mathrm{Cu}(0.79), \mathrm{Cd}(0.77), \mathrm{Co}(0.63), \mathrm{Cr}(0.65), \mathrm{Ni}(0.83), \mathrm{Hg}(0.48), \mathrm{Mn}(0.94)$ and Fe (-0.13) showed unpolluted to moderately polluted geogenically around soils of auto-mechanic workshop clusters in the Yenagoa Metropolis. Enrichment factor has shown that $\mathrm{Zn}(1.47)$ was not delivered through anthropogenic but geogenic sources while $\mathrm{Pb}$ (11.54), $\mathrm{Cu}$ (10.18), Cd (13.54), Co (4.02), $\mathrm{Cr}$ (15.35), $\mathrm{Ni}$ (13.48), Hg (8.89) and Mn (4.16) were respectively delivered anthropogenically. Fe (1.00) was the normalizer. The progressive contamination scenario observed in soils of the auto-mechanic workshop clusters in this work were mainly attributable to anthropogenic activities arising from unprofessional ways artisans adopted in disposal of heavy metal-bearing wastes onto soils of the study area. This calls for serious concern as progressive deterioration of soil quality induces negative health and environmental effects which has tendencies for affecting living organisms, on the long run.
\end{abstract}

Key words: Contamination indexes, heavy metals, soils.

\section{INTRODUCTION}

Heavy metals are persistently non-biodegradable substances in nature. They are contaminants that pose major environmental and health concerns (Vacha et al., 2012). They are primarily contained in soils from where they could be released from their bound states through either weathering of parent materials or from anthropogenic activities through which case they are introduced into completely new environments that they were formerly not found. Anwar et al. (2009) did state earlier that heavy metals have assumed a worldwide problem and pose a serious threat to the environment.
Their effects could manifest in a manifold of ways. They could contaminate food chains (Adekola et al., 2002), cause losses in food productivity (Salt et al., 1995) and public health concerns (Nwachukwu et al., 2010).

Auto-mechanic workshop clusters have been severally discovered to have contributed towards discharge of heavy metals into soils of many cities in Nigeria through disposal of heavy metal-bearing waste materials into the environment (Amukali, 2018). A number of researchers have shown overwhelming evidence suggesting how automechanic workshop clusters have contributed towards 
release of heavy metals into soils of different towns and cities in Nigeria (Iwegbue, 2007; Ipeaiyeba and Dawodu, 2008; Ilemobayo and Kolade, 2008; Nwachukwu et al., 2010; Adelekan and Abegunde, 2011; Idugboe, Tawarifufeyin and Midonu, 2014).

Auto-mechanic workshop clusters are characterized with the discharge of scrap metal dumps, waste engine oil spills as well as dumping grounds for wastes generated by welders, spray painters, panel beaters, mechanics, vulcanizers (Adelekan and Alawode, 2011) and there is need to assess the contamination status of vulnerable soils from time to time. Presently, there are scarcely any data on heavy metal contamination indexes in soils around auto-mechanic workshop clusters in the study area detailing elemental enrichment levels and origins of such heavy metals; whether natural or anthropogenic sources. This formed the basis for this work.

\section{MATERIALS AND METHODS}

\section{Study area}

Yenagoa Metropolis is headquarters of Yenagoa Local Government Area and capital of Bayelsa State (Niger Delta Development Commission, 2006). The Federal Republic of Nigeria's Gazzete (2007) estimated human population in Yenagoa Local Government Area at 353,344 people in 2006, comprising 187,791 males and 165,553 females. Yenagoa Metropolis is located between latitudes $4^{\circ} 50^{\prime} \mathrm{N}$ and $5^{\circ} 05^{\prime} \mathrm{N}$ and longitudes $6^{\circ} 15^{\prime} \mathrm{E}$ and $6^{\circ} 30^{\prime} \mathrm{E}$ and lies beside the Epie Creek (Figure 1) which empties into the Ekole Creek (Bariweni et al., 2002). Shell Petroleum Development Company (2006) classified soils of Yenagoa Metropolis as principally being rain forest soils which constitutes over $90 \%$ of the soils belonging to the Orders; Entisols, Oxisols and Alfisols, respectively. Amos-Tautau et al., (2014) emphasized that Yenagoa is located in a humid tropical wetland area with mean annual rainfall of about $2539 \mathrm{~mm}$ with an average mean temperature of $26.2^{\circ} \mathrm{C}$. SPDC (2006) stated that ambient temperature of the study area ranges from $24.5^{\circ} \mathrm{C}$ to $32^{\circ} \mathrm{C}$ during wet and $25^{\circ} \mathrm{C}$ to $36^{\circ} \mathrm{C}$ during dry seasons.

\section{Sampling design, sample preparation and analyses}

This study utilized simple random sampling technique during sample collection. Soil samples were collected by throwing a quadrant within the vicinities ( 0 meter) of the auto-mechanic workshop clusters and the control site. Materials on soil surfaces of sampled point were carefully removed before soil samples were collected to prevent such materials from interfering with the integrity of the soil samples (Pam et al., 2013). Then, a meter rule was drawn 50 meters and 100 meters away from the reference point and samples were also collected. Soil samples were collected with a stainless steel auger, dipped to appropriate depths, turned $360^{\circ}$ before removal from the soils and soil samples were then collected. At each sampled points, soil samples were collected from three soil depths (0 to $15 \mathrm{~cm}, 15$ to $30 \mathrm{~cm}$ and 30 to $45 \mathrm{~cm}$ ) over three months each during dry and wet seasons and mean values were then calculated to represent specific soil samples.

Homogenized soil samples made from collected samples were carefully put into aluminium-foil papers to prevent effects of the vagaries of weather, tied up and labeled appropriately. After which, the labeled soil samples were subjected to laboratory analysis. After every sample collection, the locations were georeferenced (Figure 1) and appropriately recorded in a notebook. The standard method of USEPA 3052 (USEPA, 1996) was adopted for sample digestion in this study while preparation and determination of heavy metals in soils followed the method of lyaka and Kakulu (2012). The method of USEPA 3052 (USEPA, 1996) were adopted for determination of heavy metals.

\section{Statistical and data analyses}

The one-way analysis of variance method used by Hoshmand (2016) was adopted in this study with levels of significance determined at $\alpha=0.05$ (Banger et al., 2010). Calculations were done using Excel Spread sheet for mean, standard deviation and Pearson Correlation Coefficients. In order to properly understand the distributional patterns of heavy metal contributions and origins to soils of the study area, i-geo and enrichment factors were used.

\section{Enrichment Factor (EF)}

The Enrichment Factor (EF) of any given metal in a given soil sample is a measure for differentiating between metals that originates from natural sources and those that originates from anthropogenic activities. It is based on the principle of standardization of a measured metal against a reference metal and a reference metal is often the one characterized by low occurrence viability (Sam et al., 2015). Examples of reference metals are Aluminium, Iron and Silicon (Sutherland et al., 2000; Zhang et al., 2009). Iron was used as the reference metal in this study. Enrichment Factor (EF) is determined by the following relationship;

$\mathrm{EFx}=\frac{\mathrm{Xs} / \mathrm{Es}(\mathrm{ref})}{\mathrm{Xc} / \mathrm{Ec}(\mathrm{ref})}$

Where EFX $=$ Enrichment Factor for an element $\mathrm{X}, \mathrm{Xs}=$ Concentration of element of interest in a given soil sample, $\mathrm{Es}(\mathrm{ref})=$ Concentration of the reference element used for 


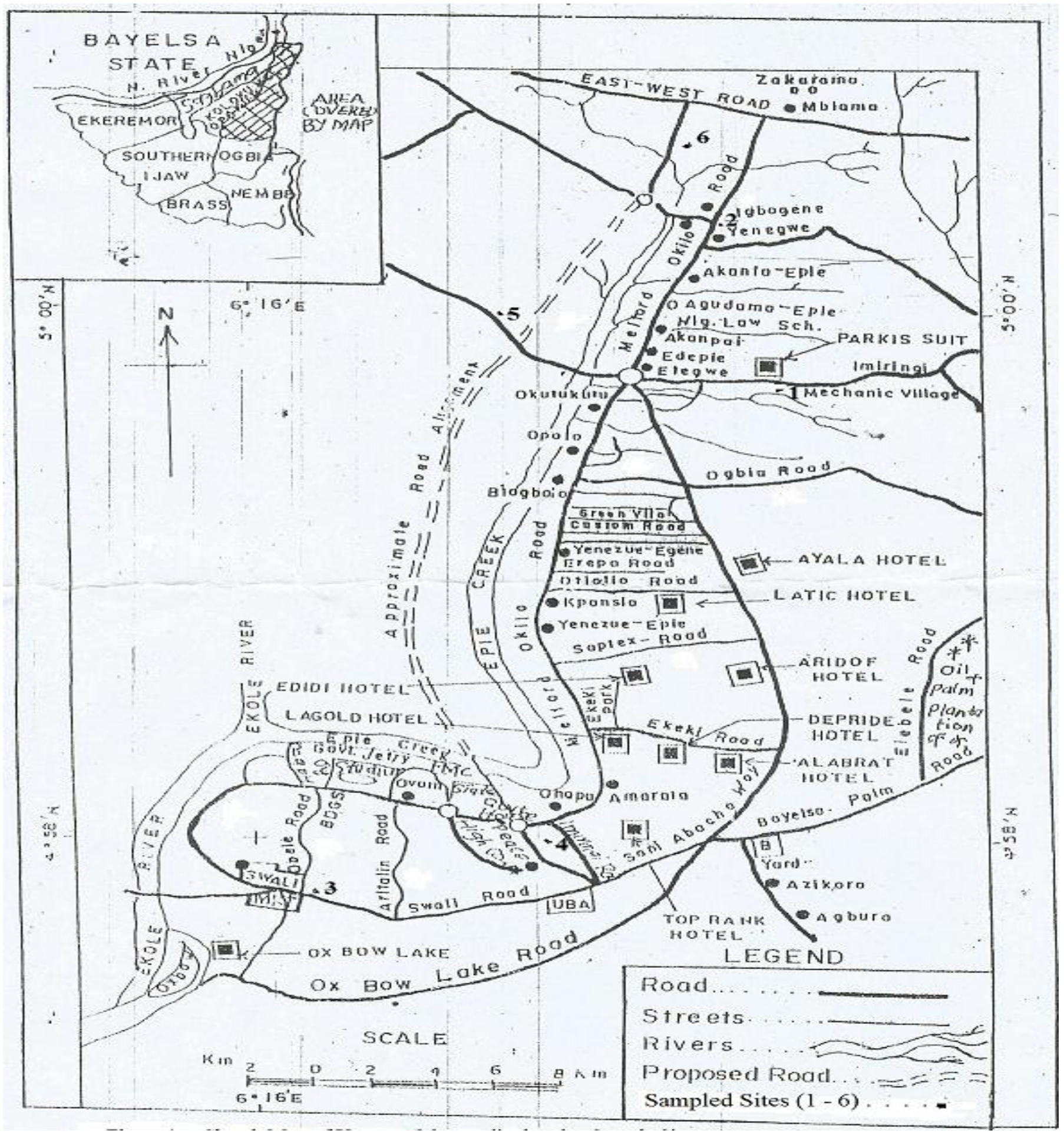

Figure 1. Map of Yenagoa metropolis showing sample sites Source: Agusomu (2015).

normalization of a given soil sample, $\mathrm{Xc}=$ Concentration of the element in the crust and Ec (ref) = Concentration of the reference element used for normalization in the crust (Taylor and McLennan,1985; Atiemo et al., 2011).

\section{Index of Geoaccumulation (i-geo)}

The index of geoaccumulation (Igeo) is a common approach employed to estimate metals enrichment above 
background or baseline concentrations in soil or sediment. The i-geo values for the studied heavy metals were calculated using the following equation developed by Muller (1969):

$\mathrm{I}-$ geo $=\log 2(\mathrm{Cn} 1.5 \mathrm{Bn})$

where $\mathrm{Cn}$ is the measured concentration of selected metal $(n)$ in the enriched soil sample and $B n$ is the is the concentration of the metal in the unpolluted (control) sample (Pam et al., 2013). The coefficient 1.5 is used to detect variations in the background data due to lithogenic and anthropogenic influences (Fagboje and Olanipekun, 2010). According to the following researchers (Muller, 1969; Fagbote and Olanipekun, 2010; Matini et al., 2011; Pam et al., 2013), I-geo consists of 7 classes (Table 2)

\section{RESULTS AND DISCUSSIONS}

The need for use of enrichment factor and i-geo as pollutant contamination indexes were due to the need to fully understand the nature of heavy metal elemental enrichment as well as establishment of the geogenic or anthropogenic contributions of heavy metals in soils of the study area.

\section{Distribution of Index of Geo-Accumulation (i-geo) in soils of the study area}

It was discovered that lead showed i-geo values that posited unpolluted status by geogenic sources across all sampled sites irrespective of soil depths and distances from the auto-mechanic workshop clusters (Tables 4 and 5). This discovery was consistent with findings in the work of Sam et al. (2015).

Same applied to values generated for cadmium, cobalt, chromium and mercury as they all showed i-geo values that were generally below (1) one. This is indicative of nongeogenic to very minimal-geogenic contribution with lead, cadmium, cobalt, chromium and mercury into all soils sampled at Imgbi, Igbogene, Imiringi, Swali as well as Etegwe auto-mechanic workshop clusters (Tables 1 and 2). In contrast, i-geo values for zinc indicated significant contamination of the soils by geogenic sources that ranged between moderately polluted to highly polluted in the study area. In addition, i-geo values for copper posited significant contributions of copper from geogenic sources for soils at Imgbi auto-mechanic workshop cluster as compared to soils encountered at Igbogene, Imiringi, Swali and Etegwe auto-mechanic workshop clusters which did not show significant i-geo values for copper, thus considered unpolluted by geogenic sources. Idugboe et al. (2014) also documented anthropogenic deposition of lead, cadmium, chromium and copper in two auto-mechanic workshop clusters in Benin City, Edo State, Nigeria.
Furthermore, i-geo values for nickel in soil samples encountered at Imgbi auto-mechanic workshop cluster showed that the soil samples that ranged from unpolluted to moderate pollution with nickel through geogenic sources. This is in agreement with the findings of llemobayo and Kolade (2008) in soils of auto-mechanic workshop clusters in Akure, Ondo State, Nigeria. Soil samples from Imiringi, Swali and Etegwe auto-mechanic workshop clusters fairly showed i-geo values that ranged from unpolluted to moderate pollution levels while i-geo values for manganese indicated unpolluted to highly polluted levels (Tables 1 and 2). This is consistent with findings of Sam et al. (2015).

Finally, it could be safely stated that the i-geo values for iron at Imgbi, Igbogene and Imiringi auto-mechanic workshop clusters were observed to be within the unpolluted status and soil samples encountered at different soil depths within the reference point ( 0 meter) of the auto-mechanic workshop clusters at Swali and Etegwe showed i-geo values are within unpolluted to moderate pollution while soil samples taken 50 meters and 100 meters away from both Swali and Etegwe auto-mechanic workshop clusters showed i-geo values that showed moderate pollution with iron (Tables 1 and 2).

Values of $\mathrm{i}$-geo as depicted in Table 3 depicted $\mathrm{Zn}$ showing moderate to highly polluted heavy metal geogenically while $\mathrm{Pb}, \mathrm{Cu}, \mathrm{Cd}, \mathrm{Co}, \mathrm{Cr}, \mathrm{Ni}, \mathrm{Hg}, \mathrm{Mn}$ and $\mathrm{Fe}$ depicted unpolluted to moderately polluted heavy metal, geogenically, within the Yenagoa Metropolis. This showed that $\mathrm{Zn}$ could be a natural resource in the study area (Sutherland et al., 2000).

\section{Overall distribution of Enrichment Factor (EF) in soils of the study area}

Lead was observed to be delivered chiefly through anthropogenic activities (Tables 4 and 5) owing to the soils showing various degrees of enrichment. Soil samples from Imgbi and Igbogene auto-mechanic workshop clusters showed moderate enrichment in some soil samples and very high enrichment to extremely high enrichment with lead in some other instances. Soil samples at Imiringi automechanic workshop cluster showed moderate enrichment to that of very high enrichment with lead while soil samples taken from Swali and Etegwe auto-mechanic workshop clusters showed evidence of deficiency to minimal enrichment to those of moderate contamination (Table 4). Enrichment factors for soil samples taken from Imgbi, Igbogene and Imiringi auto-mechanic workshop clusters were observed to show either deficiency to minimal enrichment or moderate enrichment with zinc whereas soil samples from Swali and Etegwe auto-mechanic workshop clusters showed deficiency to minimal enrichment with zinc (Tables 4 and 5). The relatively lower values observed could be partly due to the existence of zincbioaccumulating plants like $C$. digitalis which must have 
Table 1. Distribution of Index of Geo-Accumulation (i-geo) in soils of the study area.

\begin{tabular}{|c|c|c|c|c|c|c|c|c|c|c|c|c|}
\hline \multirow{2}{*}{ Site } & \multirow{2}{*}{ Distances } & \multirow{2}{*}{ Depths } & \multicolumn{10}{|c|}{ Heavy Metals $(\mathrm{mg} / \mathrm{kg})$} \\
\hline & & & $\mathbf{P b}$ & $\mathrm{Zn}$ & $\mathrm{Cu}$ & Cd & Co & $\mathrm{Cr}$ & $\mathbf{N i}$ & $\mathrm{Hg}$ & Mn & $\mathrm{Fe}$ \\
\hline \multirow{9}{*}{ Imgbi } & $0 \mathrm{~m}$ & $0-15 \mathrm{~cm}$ & 0.72 & 1.26 & 1.00 & 0.72 & 0.74 & 0.72 & 0.55 & 0.65 & 1.12 & -0.50 \\
\hline & $0 \mathrm{~m}$ & $15-30 \mathrm{~cm}$ & 0.85 & 1.36 & 1.12 & 0.72 & 0.83 & 0.49 & 0.53 & 0.72 & 0.95 & -0.76 \\
\hline & $0 \mathrm{~m}$ & $30-45 \mathrm{~cm}$ & 0.85 & 1.47 & 1.12 & 0.85 & 0.83 & 0.43 & 0.45 & 0.85 & 0.95 & -0.93 \\
\hline & $50 \mathrm{~m}$ & $0-15 \mathrm{~cm}$ & 0.60 & 1.12 & 1.00 & 0.85 & 0.83 & 0.72 & 0.50 & 0.72 & 0.95 & -0.93 \\
\hline & $50 \mathrm{~m}$ & $15-30 \mathrm{~cm}$ & 0.65 & 1.16 & 1.12 & 0.72 & 0.83 & 0.85 & 0.45 & 0.85 & 0.95 & -1.03 \\
\hline & $50 \mathrm{~m}$ & $30-45 \mathrm{~cm}$ & 0.72 & 1.19 & 1.12 & 0.85 & 0.98 & 0.85 & 0.42 & 0.85 & 0.86 & -1.12 \\
\hline & $100 \mathrm{~m}$ & $0-15 \mathrm{~cm}$ & 0.72 & 1.65 & 1.12 & 0.85 & 0.00 & 0.85 & 0.37 & 0.85 & 0.95 & -0.93 \\
\hline & $100 \mathrm{~m}$ & $15-30 \mathrm{~cm}$ & 0.72 & 1.85 & 1.31 & 0.85 & 0.00 & 0.85 & 0.28 & 0.00 & 0.95 & -0.74 \\
\hline & $100 \mathrm{~m}$ & $30-45 \mathrm{~cm}$ & 0.85 & 1.90 & 1.31 & 0.85 & 0.00 & 0.72 & 0.24 & 0.00 & 0.95 & -0.90 \\
\hline \multirow{9}{*}{ Igbogene } & $0 \mathrm{~m}$ & $5 \mathrm{~cm}$ & 0.85 & 4.19 & 0.65 & 0.72 & 0.83 & 0.72 & 0.93 & 0.85 & 0.86 & -1.01 \\
\hline & $0 \mathrm{~m}$ & $15-30 \mathrm{~cm}$ & 0.72 & 3.96 & 0.61 & 0.65 & 0.83 & 0.85 & 0.93 & 0.00 & 0.95 & -1.07 \\
\hline & $0 \mathrm{~m}$ & $30-45 \mathrm{~cm}$ & 0.65 & 3.75 & 0.54 & 0.55 & 0.83 & 0.85 & 0.84 & 0.00 & 1.12 & -1.16 \\
\hline & $50 \mathrm{~m}$ & $0-15 \mathrm{~cm}$ & 0.65 & 3.42 & 0.61 & 0.65 & 0.83 & 0.55 & 1.10 & 0.00 & 0.86 & -0.57 \\
\hline & $50 \mathrm{~m}$ & $15-30 \mathrm{~cm}$ & 0.72 & 3.16 & 0.65 & 0.72 & 0.98 & 0.65 & 1.10 & 0.00 & 0.95 & -0.69 \\
\hline & $50 \mathrm{~m}$ & $30-45 \mathrm{~cm}$ & 0.85 & 3.03 & 0.69 & 0.85 & 0.98 & 0.72 & 0.00 & 0.00 & 0.95 & -0.88 \\
\hline & $100 \mathrm{~m}$ & $0-15 \mathrm{~cm}$ & 0.72 & 2.19 & 0.56 & 0.72 & 0.00 & 0.72 & 0.00 & 0.85 & 0.95 & -1.07 \\
\hline & $100 \mathrm{~m}$ & $15-30 \mathrm{~cm}$ & 0.85 & 2.47 & 0.61 & 0.85 & 0.00 & 0.85 & 0.00 & 0.00 & 1.12 & -1.12 \\
\hline & $100 \mathrm{~m}$ & $30-45 \mathrm{~cm}$ & 0.85 & 2.55 & 0.63 & 0.85 & 0.00 & 0.85 & 0.00 & 0.00 & 1.12 & -1.26 \\
\hline \multirow{9}{*}{ Imiringi } & (iin & & 0.65 & 2.55 & 0.51 & 0.65 & 0.98 & 0.65 & 0.93 & 0.65 & 1.12 & -0.61 \\
\hline & $0 \mathrm{~m}$ & $15-30 \mathrm{~cm}$ & 0.72 & 1.44 & 0.49 & 0.72 & 0.98 & 0.72 & 1.10 & 0.65 & 1.12 & -0.56 \\
\hline & $0 \mathrm{~m}$ & $30-45 \mathrm{~cm}$ & 0.72 & 1.36 & 0.47 & 0.72 & 0.00 & 0.72 & 1.10 & 0.65 & 1.12 & -0.55 \\
\hline & $50 \mathrm{~m}$ & $0-15 \mathrm{~cm}$ & 0.72 & 1.47 & 0.61 & 0.72 & 0.98 & 0.72 & 1.10 & 0.72 & 1.12 & -0.65 \\
\hline & $50 \mathrm{~m}$ & $15-30 \mathrm{~cm}$ & 0.72 & 2.45 & 0.63 & 0.72 & 0.98 & 0.85 & 1.10 & 0.85 & 1.12 & -0.98 \\
\hline & $50 \mathrm{~m}$ & $30-45 \mathrm{~cm}$ & 0.72 & 1.69 & 0.63 & 0.72 & 0.00 & 0.85 & 1.10 & 0.72 & 1.12 & -1.18 \\
\hline & $100 \mathrm{~m}$ & $0-15 \mathrm{~cm}$ & 0.72 & 2.19 & 0.58 & 0.85 & 0.98 & 0.72 & 1.10 & 0.85 & 0.95 & -1.07 \\
\hline & $100 \mathrm{~m}$ & $15-30 \mathrm{~cm}$ & 0.72 & 2.00 & 0.58 & 0.85 & 0.83 & 0.72 & 1.10 & 0.85 & 0.95 & -1.12 \\
\hline & $100 \mathrm{~m}$ & $30-45 \mathrm{~cm}$ & 0.85 & 2.06 & 0.58 & 0.85 & 0.98 & 0.85 & 1.10 & 0.85 & 0.95 & -1.32 \\
\hline \multirow{9}{*}{ Swali } & $0 \mathrm{~m}$ & - & 0.72 & 2.12 & 0.72 & 0.65 & 0.98 & 0.85 & 1.10 & 0.65 & 0.68 & 0.75 \\
\hline & $0 \mathrm{~m}$ & $15-30 \mathrm{~cm}$ & 0.72 & 1.97 & 0.76 & 0.72 & 0.98 & 0.85 & 1.10 & 0.33 & 0.68 & 0.68 \\
\hline & $0 \mathrm{~m}$ & $30-45 \mathrm{~cm}$ & 0.72 & 2.00 & 0.76 & 0.72 & 0.83 & 0.85 & 1.10 & 0.85 & 0.73 & 0.75 \\
\hline & $50 \mathrm{~m}$ & $0-15 \mathrm{~cm}$ & 0.72 & 2.39 & 0.76 & 0.72 & 0.98 & 0.85 & 1.10 & 0.85 & 0.78 & 1.12 \\
\hline & $50 \mathrm{~m}$ & $15-30 \mathrm{~cm}$ & 0.85 & 2.32 & 0.80 & 0.85 & 0.98 & 0.85 & 1.10 & 0.85 & 0.86 & 1.01 \\
\hline & $50 \mathrm{~m}$ & $30-45 \mathrm{~cm}$ & 0.85 & 2.32 & 0.76 & 0.85 & 0.98 & 0.85 & 1.10 & 0.72 & 0.95 & 1.04 \\
\hline & $100 \mathrm{~m}$ & $0-15 \mathrm{~cm}$ & 0.85 & 2.32 & 0.80 & 0.85 & 0.98 & 0.85 & 0.93 & 0.85 & 0.86 & 1.26 \\
\hline & $100 \mathrm{~m}$ & $15-30 \mathrm{~cm}$ & 0.85 & 2.47 & 0.80 & 0.85 & 0.83 & 0.85 & 0.93 & 0.85 & 0.95 & 1.31 \\
\hline & $100 \mathrm{~m}$ & $30-45 \mathrm{~cm}$ & 0.85 & 2.39 & 0.80 & 0.85 & 0.98 & 0.85 & 0.93 & 0.85 & 0.95 & 1.32 \\
\hline \multirow{9}{*}{ Etegwe } & $0 \mathrm{~m}$ & 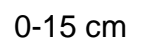 & 0.72 & 1.95 & 0.80 & 0.65 & 0.98 & 0.00 & 1.10 & 0.85 & 0.68 & 0.72 \\
\hline & $0 \mathrm{~m}$ & $15-30 \mathrm{~cm}$ & 0.72 & 2.06 & 0.80 & 0.72 & 0.98 & 0.85 & 1.10 & 0.00 & 0.68 & 0.74 \\
\hline & $0 \mathrm{~m}$ & $30-45 \mathrm{~cm}$ & 0.85 & 2.12 & 0.92 & 0.72 & 0.98 & 0.00 & 1.10 & 0.00 & 0.78 & 0.67 \\
\hline & $50 \mathrm{~m}$ & $0-15 \mathrm{~cm}$ & 0.72 & 2.45 & 0.76 & 0.72 & 0.00 & 0.85 & 1.10 & 0.00 & 0.78 & 1.16 \\
\hline & $50 \mathrm{~m}$ & $15-30 \mathrm{~cm}$ & 0.85 & 2.47 & 0.80 & 0.85 & 0.00 & 0.00 & 1.10 & 0.00 & 0.86 & 1.14 \\
\hline & $50 \mathrm{~m}$ & $30-45 \mathrm{~cm}$ & 0.85 & 2.64 & 0.85 & 0.85 & 0.00 & 0.00 & 1.10 & 0.00 & 0.95 & 1.05 \\
\hline & $100 \mathrm{~m}$ & $0-15 \mathrm{~cm}$ & 0.72 & 2.47 & 0.80 & 0.85 & 0.00 & 0.00 & 0.93 & 0.00 & 0.95 & 1.31 \\
\hline & $100 \mathrm{~m}$ & $15-30 \mathrm{~cm}$ & 0.72 & 2.39 & 0.92 & 0.85 & 0.00 & 0.00 & 0.93 & 0.00 & 0.95 & 1.34 \\
\hline & $100 \mathrm{~m}$ & $30-45 \mathrm{~cm}$ & 0.85 & 2.39 & 0.92 & 0.85 & 0.00 & 0.00 & 1.10 & 0.00 & 1.12 & 1.39 \\
\hline
\end{tabular}

Source: Amukali (2018). 
Table 2. Categories for geo-accumulation index in soils.

\begin{tabular}{ccl}
\hline S/No. & Classes & Value of soil quality \\
\hline 1 & $<0$ & Unpolluted \\
2 & $0-1$ & Unpolluted to moderately polluted \\
3 & $1-2$ & Moderately polluted \\
4 & $2-3$ & Moderately polluted to highly polluted \\
5 & $3-4$ & Highly polluted \\
6 & $4-5$ & Highly polluted to very highly polluted \\
7 & $>5$ & Very highly polluted \\
\hline
\end{tabular}

Source: Muller (1969).

Table 3. Distribution of Index of Geo-Accumulation in soils in the Yenagoa Metropolis.

\begin{tabular}{lcccccccccc}
\hline Statistical & \multicolumn{10}{c}{ Heavy Metals $(\mathbf{m g} / \mathbf{k g})$} \\
\cline { 2 - 13 } Parameters & $\mathbf{P b}$ & $\mathbf{Z n}$ & $\mathbf{C u}$ & $\mathbf{C d}$ & $\mathbf{C o}$ & $\mathbf{C r}$ & $\mathbf{N i}$ & $\mathbf{H g}$ & $\mathbf{M n}$ & $\mathbf{F e}$ \\
\hline Minimum & 0.60 & 1.12 & 0.47 & 0.55 & 0.00 & 0.00 & 0.00 & 0.00 & 0.68 & -1.32 \\
Maximum & 0.85 & 4.19 & 1.31 & 0.85 & 0.98 & 0.85 & 1.10 & 0.85 & 1.12 & 1.39 \\
Mean & 0.76 & 2.23 & 0.79 & 0.77 & 0.63 & 0.65 & 0.83 & 0.48 & 0.94 & -0.13 \\
Standard Deviation & 0.08 & 0.70 & 0.21 & 0.08 & 0.44 & 0.30 & 0.37 & 0.39 & 0.13 & 1.00 \\
\hline
\end{tabular}

Source: Amukali (2018).

helped to mop-up zinc from the study area (Amukali, 2018). Enrichment factor for copper showed that soil samples from Imgbi, Swali and Etegwe auto-mechanic workshop clusters are all within deficiency to minimal copper enrichment to those of moderate copper enrichment whereas soil samples from lgbogene and Imiringi auto-mechanic workshop clusters both showed enrichment factors that ranged from moderate enrichment to very high enrichment levels. It could be seen from Tables 4 and 5 that enrichment factors for cadmium ranged from deficiency to minimal enrichment to those of moderate enrichment in soil samples encountered at Swali and Etegwe auto-mechanic workshop clusters whereas soil samples from Imgbi, Igbogene and Etegwe automechanic workshop clusters showed from moderate enrichment to very high enrichment but later showed from very high enrichment in other instances to extremely high enrichment. Further scrutiny showed that mean concentrations of cobalt were such that the enrichment factors for cobalt were zeros in soil samples taken 100 meters away from the auto-mechanic workshop clusters at Imgbi, Igbogene and Etegwe auto-mechanic workshop clusters whereas soil samples taken within 0 meter and 50 meters from the auto-mechanic workshop clusters exhibited enrichment factors that showed moderate enrichment with copper (Table 4). Values recorded for cobalt at Imiringi and Swali auto-mechanic workshop clusters also exhibited enrichment factors that showed evidence of either deficiency to minimal enrichment or moderately enriched with copper, respectively. Sam et al. (2015) also observed a similar trend in topsoils of selected auto-mechanic workshops in Accra, Ghana.

Values of enrichment factors recorded for chromium in soil samples varied between moderate enrichment to very high enrichment in two instances at Imgbi auto-mechanic workshop cluster and varied in another instance at Igbogene auto-mechanic workshop cluster (Tables 4 and 5). Further scrutiny showed that soil samples from Imiringi auto-mechanic workshop cluster showed enrichment factor that were either moderately enriched to very highly enriched with chromium while the soil samples from Swali auto-mechanic workshop cluster showed enrichment factors that varied from deficient to minimally enriched to that of moderately enriched with chromium while soil samples collected at Etegwe auto-mechanic workshop cluster were observed to show zero enrichment with chromium except soil samples taken from the reference point ( 0 meter) at a depth of 0 to $15 \mathrm{~cm}$ and those taken 50 meters away from the auto-mechanic workshop cluster at a depth of 0 to $15 \mathrm{~cm}$ where enrichment factors were either moderately enriched or deficient to minimally enriched with chromium. Values of enrichment factors were within the ranges recorded by Adelekan and Abegunde (2011) in soils and groundwater around automechanic workshops in Ibadan, Oyo State, Nigeria and Sam et al. (2015) in topsoils around auto-mechanic workshops in Accra, Ghana.

It could be stated that soils from Imgbi auto-mechanic workshop cluster was very highly enriched with nickel within the vicinity ( 0 meter) at soil depths of 0 to $15 \mathrm{~cm}$ and 15 to $30 \mathrm{~cm}$ but extremely and highly enriched with nickel at 50 meters and 100 meters away from the auto-mechanic 
Table 4. Values for Enrichment Factor in soils of the study area.

\begin{tabular}{|c|c|c|c|c|c|c|c|c|c|c|c|c|}
\hline Location & Distances & Depths & $\mathrm{Pb}$ & $\mathrm{Zn}$ & $\mathrm{Cu}$ & Cd & Co & $\mathrm{Cr}$ & $\mathrm{Ni}$ & $\mathrm{Hg}$ & Mn & $\mathrm{Fe}$ \\
\hline \multirow{9}{*}{ Imgbi } & $0 \mathrm{~m}$ & $0-15 \mathrm{~cm}$ & 15.95 & 2.95 & 3.50 & 15.95 & 11.66 & 15.95 & 23.31 & 23.92 & 2.13 & 1.00 \\
\hline & $0 \mathrm{~m}$ & $15-30 \mathrm{~cm}$ & 9.93 & 3.42 & 2.90 & 19.86 & 9.68 & 69.51 & 31.93 & 19.86 & 5.32 & 1.00 \\
\hline & $0 \mathrm{~m}$ & $30-45 \mathrm{~cm}$ & 11.70 & 3.95 & 3.42 & 11.70 & 11.40 & 116.96 & 47.86 & 11.70 & 6.26 & 1.00 \\
\hline & $50 \mathrm{~m}$ & $0-15 \mathrm{~cm}$ & 45.77 & 4.63 & 5.02 & 11.44 & 11.15 & 22.88 & 40.13 & 22.88 & 6.12 & 1.00 \\
\hline & $50 \mathrm{~m}$ & $15-30 \mathrm{~cm}$ & 37.59 & 4.96 & 3.66 & 25.06 & 12.21 & 12.53 & 51.28 & 12.53 & 6.71 & 1.00 \\
\hline & $50 \mathrm{~m}$ & $30-45 \mathrm{~cm}$ & 26.99 & 5.23 & 3.95 & 11.50 & 6.58 & 13.50 & 67.06 & 13.50 & 10.83 & 1.00 \\
\hline & $100 \mathrm{~m}$ & $0-15 \mathrm{~cm}$ & 22.88 & 3.25 & 3.35 & 11.44 & 0.00 & 11.44 & 70.23 & 11.44 & 6.12 & 1.00 \\
\hline & $100 \mathrm{~m}$ & $15-30 \mathrm{~cm}$ & 19.49 & 2.43 & 1.43 & 9.75 & 0.00 & 9.75 & 88.32 & 0.00 & 5.22 & 1.00 \\
\hline & $100 \mathrm{~m}$ & $30-45 \mathrm{~cm}$ & 11.20 & 2.70 & 1.64 & 11.20 & 0.00 & 22.40 & 107.15 & 0.00 & 5.99 & 1.00 \\
\hline \multirow{9}{*}{ Igbogene } & $0 \mathrm{~m}$ & $0-15 \mathrm{~cm}$ & 12.24 & 0.63 & 17.89 & 24.48 & 11.93 & 24.48 & 7.16 & 12.24 & 9.83 & 1.00 \\
\hline & $0 \mathrm{~m}$ & $15-30 \mathrm{~cm}$ & 25.67 & 0.77 & 22.51 & 38.51 & 12.51 & 12.84 & 7.51 & 0.00 & 6.87 & 1.00 \\
\hline & $0 \mathrm{~m}$ & $30-45 \mathrm{~cm}$ & 41.55 & 0.95 & 30.36 & 69.25 & 13.50 & 13.85 & 12.15 & 0.00 & 3.71 & 1.00 \\
\hline & $50 \mathrm{~m}$ & $0-15 \mathrm{~cm}$ & 25.47 & 0.73 & 14.89 & 25.47 & 8.27 & 42.45 & 2.48 & 0.00 & 6.82 & 1.00 \\
\hline & $50 \mathrm{~m}$ & $15-30 \mathrm{~cm}$ & 18.80 & 0.97 & 13.74 & 18.80 & 4.58 & 28.20 & 2.75 & 0.00 & 5.03 & 1.00 \\
\hline & $50 \mathrm{~m}$ & $30-45 \mathrm{~cm}$ & 10.97 & 1.23 & 14.42 & 10.97 & 5.34 & 21.93 & 0.00 & 0.00 & 5.87 & 1.00 \\
\hline & $100 \mathrm{~m}$ & $0-15 \mathrm{~cm}$ & 25.67 & 2.54 & 26.27 & 25.67 & 0.00 & 25.67 & 0.00 & 12.84 & 6.87 & 1.00 \\
\hline & $100 \mathrm{~m}$ & $15-30 \mathrm{~cm}$ & 13.50 & 2.21 & 23.67 & 13.50 & 0.00 & 13.50 & 0.00 & 0.00 & 3.61 & 1.00 \\
\hline & $100 \mathrm{~m}$ & $30-45 \mathrm{~cm}$ & 15.04 & 2.33 & 24.18 & 15.04 & 0.00 & 15.04 & 0.00 & 0.00 & 4.02 & 1.00 \\
\hline \multirow{9}{*}{ Imiringi } & $0 \mathrm{~m}$ & $0-15 \mathrm{~cm}$ & 26.32 & 1.36 & 21.80 & 26.32 & 4.27 & 26.32 & 5.13 & 26.32 & 2.35 & 1.00 \\
\hline & $0 \mathrm{~m}$ & $15-30 \mathrm{~cm}$ & 16.71 & 2.90 & 21.98 & 16.71 & 4.07 & 16.71 & 2.44 & 25.06 & 2.24 & 1.00 \\
\hline & $0 \mathrm{~m}$ & $30-45 \mathrm{~cm}$ & 16.71 & 3.05 & 23.20 & 16.71 & 0.00 & 16.71 & 2.44 & 25.06 & 2.24 & 1.00 \\
\hline & $50 \mathrm{~m}$ & $0-15 \mathrm{~cm}$ & 18.15 & 3.07 & 15.92 & 18.15 & 4.42 & 18.15 & 2.65 & 18.15 & 2.43 & 1.00 \\
\hline & $50 \mathrm{~m}$ & $15-30 \mathrm{~cm}$ & 23.92 & 2.27 & 19.23 & 23.92 & 5.83 & 11.96 & 3.50 & 11.96 & 3.21 & 1.00 \\
\hline & $50 \mathrm{~m}$ & $30-45 \mathrm{~cm}$ & 25.67 & 4.16 & 22.87 & 28.45 & 0.00 & 14.23 & 4.16 & 28.45 & 3.81 & 1.00 \\
\hline & $100 \mathrm{~m}$ & $0-15 \mathrm{~cm}$ & 26.34 & 2.54 & 24.39 & 12.84 & 6.25 & 25.67 & 3.75 & 12.84 & 6.87 & 1.00 \\
\hline & $100 \mathrm{~m}$ & $15-30 \mathrm{~cm}$ & 26.99 & 3.02 & 25.64 & 13.50 & 13.15 & 26.99 & 3.95 & 13.50 & 7.22 & 1.00 \\
\hline & $100 \mathrm{~m}$ & $30-45 \mathrm{~cm}$ & 15.95 & 3.43 & 30.30 & 15.95 & 7.77 & 15.95 & 4.66 & 15.95 & 8.54 & 1.00 \\
\hline \multirow{9}{*}{ Swali } & $0 \mathrm{~m}$ & $0-15 \mathrm{~cm}$ & 5.60 & 0.64 & 3.27 & 8.40 & 1.36 & 2.80 & 0.82 & 8.40 & 4.50 & 1.00 \\
\hline & $0 \mathrm{~m}$ & $15-30 \mathrm{~cm}$ & 5.95 & 0.73 & 3.04 & 5.95 & 1.45 & 2.97 & 0.87 & 8.92 & 4.77 & 1.00 \\
\hline & $0 \mathrm{~m}$ & $30-45 \mathrm{~cm}$ & 5.60 & 0.67 & 2.86 & 5.60 & 2.73 & 2.80 & 0.82 & 47.59 & 3.75 & 1.00 \\
\hline & $50 \mathrm{~m}$ & $0-15 \mathrm{~cm}$ & 4.14 & 0.38 & 2.12 & 4.14 & 1.01 & 2.07 & 0.61 & 2.07 & 2.22 & 1.00 \\
\hline & $50 \mathrm{~m}$ & $15-30 \mathrm{~cm}$ & 2.26 & 0.41 & 1.98 & 2.26 & 1.10 & 2.26 & 0.66 & 2.26 & 1.81 & 1.00 \\
\hline & $50 \mathrm{~m}$ & $30-45 \mathrm{~cm}$ & 2.19 & 0.40 & 2.24 & 2.19 & 1.07 & 2.19 & 0.64 & 4.39 & 1.17 & 1.00 \\
\hline & $100 \mathrm{~m}$ & $0-15 \mathrm{~cm}$ & 1.84 & 0.33 & 1.61 & 1.84 & 1.79 & 1.84 & 1.08 & 1.84 & 1.48 & 1.00 \\
\hline & $100 \mathrm{~m}$ & $15-30 \mathrm{~cm}$ & 1.78 & 0.29 & 1.56 & 1.78 & 0.87 & 1.78 & 1.04 & 1.78 & 0.95 & 1.00 \\
\hline & $100 \mathrm{~m}$ & $30-45 \mathrm{~cm}$ & 1.74 & 0.30 & 1.53 & 1.74 & 0.85 & 1.74 & 1.02 & 1.74 & 0.93 & 1.00 \\
\hline \multirow{9}{*}{ Etegwe } & $0 \mathrm{~m}$ & $0-15 \mathrm{~cm}$ & 5.51 & 0.64 & 2.42 & 8.27 & 1.34 & 0.00 & 0.81 & 2.76 & 4.43 & 1.00 \\
\hline & $0 \mathrm{~m}$ & $15-30 \mathrm{~cm}$ & 5.72 & 0.62 & 2.51 & 5.72 & 1.39 & 2.86 & 0.84 & 0.00 & 4.59 & 1.00 \\
\hline & $0 \mathrm{~m}$ & $30-45 \mathrm{~cm}$ & 3.01 & 0.62 & 1.76 & 6.02 & 1.47 & 0.00 & 0.88 & 0.00 & 3.22 & 1.00 \\
\hline & $50 \mathrm{~m}$ & $0-15 \mathrm{~cm}$ & 3.99 & 0.38 & 2.04 & 3.99 & 0.00 & 1.99 & 0.58 & 0.00 & 2.13 & 1.00 \\
\hline & $50 \mathrm{~m}$ & $15-30 \mathrm{~cm}$ & 2.02 & 0.33 & 1.78 & 2.02 & 0.00 & 0.00 & 0.59 & 0.00 & 1.63 & 1.00 \\
\hline & $50 \mathrm{~m}$ & $30-45 \mathrm{~cm}$ & 2.18 & 0.32 & 1.60 & 2.18 & 0.00 & 0.00 & 0.64 & 0.00 & 1.17 & 1.00 \\
\hline & $100 \mathrm{~m}$ & $0-15 \mathrm{~cm}$ & 3.52 & 0.29 & 1.55 & 1.77 & 0.00 & 0.00 & 1.03 & 0.00 & 0.95 & 1.00 \\
\hline & $100 \mathrm{~m}$ & $15-30 \mathrm{~cm}$ & 3.42 & 0.29 & 1.00 & 1.71 & 0.00 & 0.00 & 1.00 & 0.00 & 0.92 & 1.00 \\
\hline & $100 \mathrm{~m}$ & $30-45 \mathrm{~cm}$ & 1.65 & 0.28 & 1.20 & 1.65 & 0.00 & 0.00 & 0.48 & 0.00 & 0.44 & 1.00 \\
\hline
\end{tabular}

Source: Amukali, (2018). 
Table 5. Classes for categorization of pollution status based on Enrichment Factor in soils.

\begin{tabular}{|c|c|c|}
\hline S/No. & Classes & Value of soil quality \\
\hline \multicolumn{3}{|c|}{ On the basis of differentiation based on the origins; natural or anthropogenic } \\
\hline 1 & $E F>1.5$ & suggests metals delivered by anthropogenic sources, \\
\hline 2 & $E F<2$ & suggests minimal elemental enrichment and \\
\hline 3 & $E F>2$ & suggests various degrees of metal enrichment (Fagboje and Olanipekun, 2010) \\
\hline \multicolumn{3}{|c|}{ On the basis of degree of enrichment } \\
\hline 1 & $\mathrm{EF}<2$ & indicates deficiency to minimal enrichment \\
\hline 2 & $2 \leq \mathrm{EF} \geq 20$ & indicates moderate enrichment \\
\hline 3 & $20<\mathrm{EF} \geq 40$ & indicates very high enrichment and \\
\hline 4 & $E F>40$ & indicates extremely high enrichment. \\
\hline
\end{tabular}

Sources: Sam et al., (2015).

Table 6. Overall Values of Enrichment Factors in soils in the Yenagoa Metropolis.

\begin{tabular}{lcccccccccc}
\hline Statistical Parameters & $\mathbf{P b}$ & $\mathbf{Z n}$ & $\mathbf{C u}$ & $\mathbf{C d}$ & $\mathbf{C o}$ & $\mathbf{C r}$ & $\mathbf{N i}$ & $\mathbf{H g}$ & $\mathbf{M n}$ & $\mathbf{F e}$ \\
\hline Minimum & 1.65 & 0.28 & 1.00 & 1.65 & 0.00 & 0.00 & 0.00 & 0.00 & 0.44 & 1.00 \\
Maximum & 45.77 & 5.23 & 30.36 & 69.25 & 13.50 & 116.96 & 107.15 & 47.59 & 10.83 & 1.00 \\
Mean & 14.43 & 1.47 & 10.18 & 13.54 & 4.02 & 15.35 & 13.48 & 8.89 & 4.16 & 1.00 \\
SD & 11.54 & 1.48 & 10.15 & 12.39 & 4.61 & 20.49 & 25.69 & 10.82 & 2.54 & 0.00 \\
\hline
\end{tabular}

Source: Amukali (2018).

workshop clusters for all soil samples collected in this study (Tables 4 and 5). Furthermore, enrichment factors for nickel at Igbogene, Imiringi, Swali and Etegwe automechanic workshop clusters were within deficient to minimally enriched to moderate enrichment with nickel, though in a few instances, zero enrichment factors were recorded (Table 4). For mercury, it was noticed that all values for the enrichment factors for Igbogene and Etegwe auto-mechanic workshop clusters showed zero except at the reference point $(0$ meter) at Igbogene auto-mechanic workshop cluster at a depth of 0 to $15 \mathrm{~cm}$ and 100 meters at a depth of 0 to $15 \mathrm{~cm}$ which showed enrichment factors that were moderately enriched with mercury. Values of Mercury in this study were below those recorded by Sam et al. (2015).

On the other hand, enrichment factors for mercury at Imgbi, Imiringi and Swali auto-mechanic workshop cluster all showed evidence of deficient/minimally enriched, moderately enriched or very highly enriched with mercury. This is an indication that geogenic sources could not be held accountable for the levels of mercury recorded in this present study, rather, anthropogenic activities emanating from disposal of heavy metal-bearing waste materials within and around the auto-mechanic workshop clusters should be responsible. The control site lacked mercury in all soil depths and distances considered in this study. The levels of mercury encountered in this study were less than those reported by Gochfeld (2003). It was also observed that manganese showed enrichment factors that were within the deficient/minimally enriched to moderate enrichment with manganese for all soil samples encountered in all sampled areas in this study. Finally, it is noteworthy to re-emphasize that iron was used as a normalizer for the other heavy metals thus showed enrichment factor values that were within deficient/minimally enriched (Table 4).

\section{Overall distribution of Enrichment Factor (EF) in soils in the Yenagoa metropolis}

Enrichment factor has shown that $\mathrm{Zn}$ (1.47) was not delivered through anthropogenic but geogenic sources while $\mathrm{Pb}$ (11.54), Cu (10.18), Cd (13.54), Co (4.02), Cr (15.35), $\mathrm{Ni}(13.48), \mathrm{Hg}(8.89)$ and $\mathrm{Mn}$ (4.16) were delivered through anthropogenic influences while $\mathrm{Fe}(1.00)$ was the normalizer (Table 6) in this study. This implied that anthropogenic influences with regards to discharge of heavy metals into soils of auto-mechanic workshop clusters in the Yenagoa Metropolis has serious cause for concern owing to increasing levels of the heavy metals in the soils.

\section{Conclusion}

It was observed that the elemental contributions from the ten (10) heavy metals considered varied from one heavy metal to the other. Specifically, lead was observed to show 
Glo. J. Earth Environ. Sci.

the greatest elemental enrichment spread at all automechanic workshop clusters sampled as it was found to show from considerable to very high contamination status in soils of most of the auto-mechanic workshop clusters. Soils of the five (5) auto-mechanic workshop clusters were generally observed to show from moderate degrees to very high degrees of contamination. In addition, evidence of progressive deterioration of soils of Imgbi, Imiringi and Swali were observed.

Finally, it was observed that anthropogenic activity like disposal of heavy metal-bearing waste materials within the study area was responsible for the levels of lead, cadmium, cobalt, chromium, mercury at all the automechanic workshop clusters and copper in soils at Igbogene, Imiringi, Swali and Etegwe auto-mechanic workshop clusters. It was further noted that zinc and copper as well as nickel in soils at Imgbi auto-mechanic workshop cluster were generated through geogenic sources. Same for manganese encountered in soil samples from Imiringi, Swali and Etegwe auto-mechanic workshop clusters and Iron in soils at 0 meter at Imgbi, Igbogene and Imiringi auto-mechanic workshop clusters were all found to have been generated through geogenic sources at the study area.

Values of i-geo showed that $\mathrm{Zn}$ showed moderate to highly polluted geogenically while $\mathrm{Pb}, \mathrm{Cu}, \mathrm{Cd}, \mathrm{Co}, \mathrm{Cr}, \mathrm{Ni}$, $\mathrm{Hg}, \mathrm{Mn}$ and $\mathrm{Fe}$ showed unpolluted to moderately polluted geogenically around soils of auto-mechanic workshop clusters in the Yenagoa Metropolis. Enrichment factor has shown that $\mathrm{Zn}$ was not delivered through anthropogenic but geogenic sources while evidence existed that $\mathrm{Pb}, \mathrm{Cu}$, $\mathrm{Cd}, \mathrm{Co}, \mathrm{Cr}, \mathrm{Ni}, \mathrm{Hg}$ and $\mathrm{Mn}$ were delivered anthropogeniccally. Fe was the normalizer in this study. The $\mathrm{Zn}$ should possibly be from those specifically bound to organic matter contents of soils in the study. The progressive contamination scenario observed in soils of the automechanic workshop clusters in this work were mainly attributable to anthropogenic activities arising from unprofessional ways artisans adopted in disposal of heavy metal-bearing wastes onto soils of the study area. This calls for serious health and environmental concern as progressive deterioration of soil quality could lead to food chain contamination. Finally, heavy metal pollution could result from indiscriminate waste disposal and unprofessional practices on the part of artisans working in auto-mechanic workshop clusters, thus they should be well regulated to prevent them from inducing toxic, terratogenic and carcinogenic effects in man.

\section{CONFLICT OF INTEREST}

The authors declare that they have no conflict of interest.

\section{REFERENCES}

Adekola, F. A., Eletta, O. A., \& Atanda, S. A. (2002). Determination of the levels of some heavy metals in urban run- off sediments in llorin and Lagos, Nigeria. Journal of Applied Sciences and Environmental Management, 6(2), 23-26.

Adelekan, B. A., \& Abegunde, K. D. (2011). Heavy metals contamination of soil and groundwater at automobile mechanic villages in Ibadan, Nigeria. International Journal of Physical Sciences, 6(5), 1045-1058.

Adelekan, B. A. and Alawode, A. O. (2011). Concentrations of muncipal refuse dumps to heavy metals concentrations in soil profile and ground water at Ibadan, Nigeria. Journal of Appled Bioscience, 40, 2727-2737.

Agusomu, T. D. (2015). Sketch map of Yenagoa Metropolis in Yenagoa Local Government Area of Bayelsa State, Nigeria.

Amos-Tautau, B. M. W., Onigbinde, A. O., \& Ere, D. (2014) Assessment of some heavy metals and physicochemical properties in surface soils of municipal open waste dumpsite in Yenagoa, Nigeria. African Journal of Environmental Science and Technology, 8(1), 41-47.

Amukali, O. (2018). Spatial distribution of heavy metals in soils and plants growing around automobile mechanic workshop clusters in Yenagoa Metropolis, Nigeria. An Unpublished PhD Thesis submitted to The Postgraduate School, Niger Delta University, Amassoma, Bayelsa State, Nigeria. 387p.

Anwar, J, Shafique, U, Salman, M, Zaman, W, Anwar, S., \& Anzano, J. (2009). Removal of Chromium (III) by using coal as adsorbent. Journal of Hazardous Materials. 171, 797-801.

Atiemo, M., Ofosu F. G., Aboh, I. J. K., \& Oppon, O. C. (2011). Levels and sources of heavy metal contamination in road dust in selected major highways of Accra, Ghana. Sampson X-Ray Spectrometry, 41(2), 105-110.

Banger, K., Toor, G. S., Chirenje, T. and Ma, L. (2010). Polycyclic aromatic hydrocarbons in urban soils of different land uses in Miama, Florida. Soil and Sediment Contamination, 19, 231 243.

Bariweni, P. A., Izonfuo, W. L., \& Amadi, E. N. (2002). Domestic waste levels and assessment of their current management startegies in Yenagoa Metropolis. Global Journal of Environmental Sciences, 1(1), 15-19.

Fagbote, E. O., \& Olanipekun, E. O. (2010). Evaluation of the status of heavy metal pollution of soil and plant (Chromolaena odorata) of Agbabu Bitumen Deposit Area, Nigeria. AmericanEurasian Journal of Scientific Research, 5(4), 241-248.

Gochfeld, M. (2003). Cases of mercury exposure, bioavailability, and absorption. Ecotoxicology and Environmental Safety, 56(1), 174-179.

Hoshmand, R. A. (2016). Design of Experiments for Agriculture and the Natural Sciences. CRC Press, Boca Raton, Florida. $145 \mathrm{p}$.

Idugboe, S. O., Tawari-Fufeyin, P., \& Midonu, A. A. (2014) Soil Pollution in Two Auto-Mechanic Villages in Benin City, Nigeria. J. Environ. Sci. Toxic. Food Technol., 8(1), 09-14.

Ilemobayo, O., \& Kolade, I. (2008). Profile of heavy metals from automobile workshops in Akure, Nigeria. Journal of Environmental Science and Technology, 1(1), 19-26.

Iwegbue, C. M. (2007). Metal fractionation in soil profiles at automobile mechanic waste dumps. Waste Management and Research, 25(6), 585-593.

lyaka, Y. A., \& Kakulu, S. E. (2012). Topsoil contamination by heavy metals from a local brass industrial area of Nigeria. Resources and Environment, 2(1), 86-89.

Matini, L., Ongoka, P. R., \& Tathy, J. P. (2011). Heavy metals in soil on spoil heap of an abandoned lead ore treatment plant, SE Congo-Brazzaville. African Journal of Environmental Science and Technology, 5(2), 89-97.

Muller, G. (1969). Index of geoaccumulation in sediments of the 
Rhine River. Geojournal, 2, 108-118.

Niger Delta Development Commission (2006) Niger Delta Regional Development Plan. Printing Development Commission Limited, NDDC, Port-Harcourt, Nigeria. 258p.

Nwachukwu, M. A., Feng, H., \& Achilike, K. (2010). Integrated study for automobile wastes management and environmentally friendly mechanic villages in the Imo River Basin, Nigeria. African Journal of Environmental Science and Technology, 4(4), 234-249.

Pam, A. A., Sha'Ato, R., \& Offem, J. O. (2013). Evaluation of heavy metals in soils around auto mechanic workshop clusters in Gboko and Makurdi, Central Nigeria. Journal of Environmental chemistry and ecotoxicology, 5(11), 298-306.

Salt, D. E., Blaylock, M., Kumar, N. P. B. A., Dusenkov, V., Ensley, B. D., Chet, I., \& Raskin, I. (1995). Phytoremediation: A Noval Strategy for the Removal of Toxic Metals from the Environment using Plants. Biotechnology, 13, 468-474.

Sam, R. A., Ofosu, F. G., Atiemo, S. M., Aboh, I. J. K., Gyampo, O., Ahiamadjie, H., ... \& Arthur, J. K. (2015). Heavy metal contamination levels in topsoil at selected auto workshops in Accra. International Journal of Science and Technology, 4(5), 222-229.

Shell Petroleum Development Company (2006). Final Report of the Environmental Impact Assessment (EIA) of Rumuekpe (OML 22) and Etelebou (OML 28) 3D Seismic Survey. SPDC Press, Portharcourt. 393p.
Sutherland, R. A., Tolosa, C. A., Tack, F. M. G., \& Verloo, M. G. (2000). Characterization of selected element concentrations and enrichment ratiosin background and anthropogenically impacted roadside areas. Archives of Environmental Contamination and Toxicology, 38(4), 428-438.

The Federal Republic of Nigeria's Gazzete (2007).

Taylor, S. R., \& McLennan, S. M. (1985). The Continental Crust: Composition and Evolution. Blackwell Scientific Publications, Oxford. 78p.

USEPA (1996) Soil Screening Guidance: Technical Background Document. USEPA Rep. 540/R-95/128. US Gov. Print. Office, Washington, DC. 121p.

Vacha, R., Checmankova, J., \& Skála, J. (2012). Polycyclic Aromatic Hydrocarbons in Soil and Selected Plants. Research Institute of Soil and Water Conservation, Prague, Czech Republic. Pp. 434-443.

Zhang, L., Tian, S., Ye. Z., \& Wang, Q. (2009) The Efficiency of Heavy Metal Removal from Contaminated Water by Elsholtzia argi and Elsholtzia splendens; Proc. of the International Symposium of Phytoremediation and Ecosystem Health; Sept. 10-13; Hangzhou, China. 